\title{
AMERICAN FOREIGN POLICY TOWARDS EGYPT UNDER HOSNI MUBARAK'S REGIME
}

Egypt's geopolitical location has always been of considerable significance to the international relations in the Middle East, North Africa as well as the countries of the Arab Peninsula. Due to the highly strategic position, political events transpiring in Egypt have also been carefully followed by states worldwide, including superpowers like the United States. The aim of this paper is to provide a systematic overview of the American policy towards Egypt during the multi-term presidency of Hosni Mubarak spanning over two decades of a highly transitive time in the Middle East. Considering multiple problematic issues of political nature as well as military conflicts and campaigns of the time, the U.S. government had to seek solutions to involve Egypt, particularly in its political agenda associated with the Middle East. The material provided below illustrates the dynamics of American policy towards Egypt during various key events and operations, including the First and Second Gulf War, and the long-running Arab-Israeli Conflict.

Although the compiled and analyzed material focuses on the American standpoint and relevant resolutions, references to $\mathrm{H}$. Mubarak's personality, career and political style must be included as triggering the development American policy towards Egypt. As the subsequent section shall reveal, while H. Mubarak's reins originally continued from the point where the late President Sadat had untimely finished his duties, the country would eventually develop a course of progress diverging considerably from its previous path. Needless to say, the American government would have to realign its policies accordingly.

While this paper concentrates on the reins of a single president, whose rule over time transformed into a more authoritarian form of dictatorship, it only requires basic geographical knowledge to understand the position of Egypt in both the Middle East and Northern Africa, not to mention its socio-cultural and political relationship with the countries of the Arab Peninsula. Thus, the inclusion of Egypt in the American foreign policy-making is inherent in superpower's political activities (Jordan and Pauly, 2007: 157-158).

Lastly, one may also consider the Egyptian Synai Peninsula as symbolic to Egypt's position - the land lies in Asia, whilst the 'main' part of the country is situated on the African continent. A comprehensive historical perspective on the significance of Egypt in the region is beyond the scope of this paper, as it spans several millennia and empires - from Pharaoh's rule through the position as a chief Muslim state between mid- $13^{\text {th }}$ and early $16^{\text {th }}$ century, to the lessening of power associated with the growth of the Ottoman Empire, and its later gradual fall. 
From the methodological perspective, this paper relies on an investigation of the available reports and factual evidence previously collected by the scholars and representative media of long-running reputation. A sense of balance was maintained between printed publications, including edited books, journal articles, and press articles, and online resources from recognized media agencies. While the study concentrates on the recently published sources, the relatively older publications are referred to so as to confirm the stability of certain historical facts and events. The qualitative aspects of "when" and "how" are crucial to the offered compilation of factual knowledge and opinions.

\section{MUBARAK'S RISE TO POWER AND THE AMERICAN POLICY}

The time of Hosni Mubarak's presidency symbolizes two over decades of solid cooperation between Egypt and the United States. It must be remembered that Mubarak's ascension to presidency occurred due to the assassination of his predecessor Anwar Al-Sadat in 1981. At that time, H. Mubarak had already been vice-president and a highly influential political figure involved in multiple international affairs. President Sadat would request Mubarak to attend numerous meetings and conferences featuring leaders of other countries, both within and outside the Arab circle. H. Mubarak's position on the political arena in the region is underlined by various sources already during his vice-presidency. During a conversation of June 23, 1975, held between Nabil Fahmy, Egyptian Foreign Minister, and the American Ambassador Hermann Eilts, it was overtly expressed that "Mubarak is [...] likely to be a regular participant in all sensitive meetings"; the Ambassador was also advised not to act in opposition to Mubarak due to the fact that he had been personally appointed by Sadat to represent Egypt's business during international meetings (Mubarak: from..., 2011). In another memorandum of a declassified conversation with President Ford and Secretary of State, Henry A. Kissinger, Eilts refers to Mubarak as "[Egyptian] Army's eyes and ears" (Foreign Relations Of The United States, 1969-1976).

El Tohamy metaphorizes H. Mubarak's early presidency as "picking up" Sadat's reins, which illustrates the point made in this paragraph - the new president did not revert or void any diplomatic agreements reached earlier, nor did he antagonize the late President Sadat; in fact, Mubarak referred to his predecessor as "hero of war and peace" (El Tohamy, 1981: 2).

A crucial early point signifying H. Mubarak's attitude towards American involvement and interests in the Middle East is marked by his perception of the Camp David Accords from 1978 establishing, among others, peaceful relations between Egypt and Israel. Unlike in the case of Sadat's long-running efforts to restore the Egyptian control of the Sinai Peninsula which got Mubarak's authentic and active support, the new President shared the perspectives of most Arab leaders that the aforementioned Camp David Accords utterly failed to resolve other key issues in the region, notably the Arab-Israeli conflict (ibidem).

The USA, however, allowed H. Mubarak to voice his doubts and criticism without consequences, as he did not actively oppose the American involvement. 
Moreover, it is also necessary to consider the fact that at the dawn of the $21^{\text {st }}$ century Egypt boasted the second largest army in the entire Middle East that was only surpassed in number by Iran. Overall, the country's military potential ranked it as the $13^{\text {th }}$ military power in the world. Needless to say, the USA perceived Egypt as a crucial partner in the region, and recognized Mubarak as a proven military leader, hence apart from the fact that the Egyptian president was allowed much freedom in his activities, the United States has additionally been supporting Cairo with USD 1.3 billion intended purely for military expenses. This line of support was introduced by President Jimmy Carter following the successful conclusion and signing of the Camp David Accords, and has not been terminated until the present day (Jordan, Pauly, 2007: 158).

The United States had to adjust to the leader whose rein would rely on cold calculation, pre-planning, unwillingness to improvise and act quickly, and 'controlled' risk taking. Symbolically, Mubarak would not venture to improvise lengthy speeches or oratory performances during diplomatic meetings. This observation may occur to be in apparent contrast to the fact presented earlier that Sadat would regularly appoint Mubarak to represent Egypt during international meetings abroad. El Tohamy clarifies the matter by explaining that Mubarak's role was more of a messenger than a bona fide diplomatic envoy (El Tohamy, 1981:2). Thus, what the USA could expect was a strict and calculated leader with moderate skills at foreign diplomacy, and hence oriented towards the control of internal affairs. Thus, while the considerable American contribution to Egypt's military development could be perceived as risky, as in the case of military conflict between Egypt and Israel, the former country would become a powerful enemy, the superpower did not withhold its support, but watched the activities of President Mubarak with incessant attention. According to the previously classified documents available presently via WikiLeaks, the American diplomacy developed a detailed psychological, ideological and even medical portrait of the Egyptian leader to be considered in the process of policy-making (Scobey, 2009).

What is more, H. Mubarak was aware of his skills as well as his limitations, thus he would not venture into the unknown regarding both internal and foreign matters. For the nation, the leader appeared as a calm, sober and dignified successor to Sadat. The new president also proved himself as a man of consequence: while he did express his regrets over the tragic repercussions of peace between Egypt and Israel, he held a firm opinion that the restoration of Egyptian rule over the Sinai Peninsula counted as Sadat's most remarkable achievement - Mubarak ensured that the retreating Israeli troops maintain the conditions of the peace treaty, earning respect and increased support among his citizens (ibidem). For America, what stemmed from Egyptian president's political consistency was that partnership with Egypt meant the power to influence the Middle East and the opinions in the Arab world. Jordan and Pauly stress that the impact of Egyptian policy would directly affect other states in the area, whether the political or ideological discourse would be of Islamic or secular nature (Jordan, Pauly, 2007: 158).

It should be mentioned that before Libya's suspended membership in the Arab League at the onset of the Libyan Civil War, Egypt had been the only state in the region to have been subject to such a suspension. It was directly caused by President Sadat's finalized peace treaty with Israel. However, in 1989, Egypt's rights as a member-state 
were restored to their full extent; moreover, the League's headquarters moved to their original location in Cairo (ibidem: 168).

The course of events proved highly beneficial for the United States, who could count on their long-time ally to represent the American voice in the League. The advantage was mutual, as Egypt, enjoying its restored and improved position in the region, could secure the inflow of American financial aid.

\section{EGYPT'S EMERGENCE AND DEVELOPMENT AS US STRATEGIC ALLY IN THE MIDDLE EAST}

At the dawn of the last decade of the $20^{\text {th }}$ century, during the first Gulf War Egypt joined the allied coalition against Iraq. In fact, in 1991 Egyptian infantry were some of the first troops to land in the area of north-east Saudi Arabia with the objective of driving Iraqi forces from the occupied Kuwait. The American Government described Egypt's presence in the coalition as crucial in obtaining a wider support among Arab countries, and their active involvement in the liberation of Kuwait. It needs to be stressed that Egypt's participation and its active role in the military campaign was recognized and duly rewarded by the USA within the International Monetary Fund (IMF). According to "The Economist":

\footnotetext{
"The program worked like a charm: a textbook case, says the International Monetary Fund. In fact, luck was on Hosni Mubarak's side; when the US was hunting for a military alliance to force Iraq out of Kuwait, Egypt's president joined without hesitation. After the war, his reward was that America, the Arab states of the Persian Gulf, and Europe forgave Egypt around \$20 billion of debt" (The IMF's, 1999).
}

“The Economist” goes as far as to call Egypt IMF's 'model pupil' - a state whose resultant economic growth could leverage the losses incurred by foreign financial institutions stemming from granted reductions of Egypt's national debt. IMF's local observer confirmed that in 1998 the country no longer required financial 'handicaps' to accelerate its economic growth. What is more, participation in the victorious campaign solidified Egypt's key role in the Middle East. H. Mubarak could continue the economic development of the country that had already begun in the 1980s. Affordable housing options were developed and offered to people; the country also improved its textile industry to offer cheap garments. Citizens were given access to inexpensive local products including pharmaceuticals (The IMF's, 1999). Thus, to use Neack's terminology, Egypt was no longer a 'client state' of the United States - it was voluntarily a financially supported political and military ally as well as an independent ideological representative (Neack, 2013: 188).

Mubarak's tendency towards maintaining harmony through tight control could already be observed during his first term as President of Egypt. The leader would closely monitor his subordinates and officials. Ministers could be dismissed whenever they would be accused or suspected of wrongdoing. Members of parliament could be fined for unexcused absences. It is also noteworthy that despite the aforesaid acceptance of the Camp David Accords, H. Mubarak represented the minority of Egyptian officials officially refusing to visit Israel. The politician understood the necessity of maintaining 
peace, especially following the victory at the east coast of the Suez Canal, and yet he made a solemn vow to assume a 'cold' approach to the normalization of diplomatic relations with Israel (El Tohamy, 1981: 3).

The United States did not find H. Mubarak to be a threat to their interests in the Arab territories, especially that the Egyptian president continued to underline that his political attitudes would not lead to Egyptian-Israeli tensions or crises in the future. Mubarak did not intend to endanger relations with the USA, as his country was heavy dependent on American aid programs. Furthermore, Egypt hoped that the superpower would increase pressure on Israel to reach a settlement with Palestine.

The lenient and instrumental approach to Egypt during Mubarak's regime led to the negligence of the basic ideals of democracy. This is best illustrated using the words of U.S. Secretary of State Condoleezza Rice during a post-9/11 speech:

"We should all look to a future when every government respects the will of its citizens
- because the ideal of democracy is universal. For 60 years, my country, the United
States, pursued stability at the expense of democracy in this region here in the Middle
East - and we achieved neither. Now, we are taking a different course. We are support-
ing the Second inaugural Address: »America will not impose our style of government
on the unwilling. Our goal instead is to help others find their own voice, to attain their
own freedom, and to make their own way«" (Kalpakian, 2007: 217).

The quoted speech represented part of a larger overall strategy referred to as the Middle East Partnership Initiative (MEPI). Ironically, the invasion of Iraq commenced two years later was in no way related to the program. Still, MEPI proved to be an important American step towards improving the relations with the entire Arab League. Compared to the bilaterally beneficial implemental approach to maintaining and developing Egypt's support, MEPI constituted one of the few American initiatives considering the whole region as a socio-political collective sharing a core set of values and beliefs. While Kalpakian admits that the program was not perfect, it was symbolic to the soft edge of the United States policy concentrating on offering aid without altering the institutional culture of the region (ibidem: 217-218).

In the case of Mubarak's regime, though, the situation was different. Egypt had been enjoying substantial financial aid, and its leader was virtually unconstrained to introduce reforms and policy changes - however, the USA decided to turn the blind eye towards Mubarak's evident sway towards authoritarianism and power abuse.

However, H. Mubarak simultaneously attempted to improve, albeit in a rather inconspicuous manner, Egypt's relationship with the Soviet Union and later the post-Soviet Russia - the United States did not oppose, as Egyptian president's intentions were based mostly on economic grounds and aiming to further improve Egypt condition in the region. Hosni Mubarak's predecessor had broken diplomatic relations with the Soviet Union shortly before his assassination, and the current leader found the situation 'unnatural' and simply impractical, considering the economic and technological opportunities (McDermott, 2013: 86). It must also be remembered that Egypt at that time had considerable military debts to the Soviet Union whose repayment had been halted by President Sadat. Thus, the resultant agreements and established partnerships were of economic nature, not disturbing the dynamics of the cooperation between Egypt and the United States (ibidem). 
Considering the state of affairs, and H. Mubarak's achievements for his country throughout the 1980s, it came as no surprise that he was reelected in 1987 for another six-year term. It was also an important message to the United States. According to "The Economist", Mubarak's continuing reins, albeit facilitated through largely undemocratic election process, represented a simple means to preserving political stability in Egypt, and justified maintaining the existing support plans for America's major partner in the Middle East (The IMF's, 1999).

Financial aid and support offered to Egypt could be considered a safe investment by the United States - not only because Mubarak was a rational and calculating leader, who would not refuse an opportunity to accelerate the internal development of Egypt, in return for political loyalty, but also due to his stance against Islamic fundamentalism. His position against extremism was firm, as demonstrated through numerous failed assassinations attempts that did not cause the president to alter his views (Profile: Hosni, 2014). Instead, H. Mubarak would tighten his grip on the suspected factions in the society. The leader would demonstrate his attitude towards revolutionary religious movements in June 1995. After an attempted assassination - a scheme involving lethal gases and Egyptian Islamic jihadists during H. Mubarak's stay in Ethiopia - Hosni Mubarak allegedly authorized bombings on fundamentalist settlements, plus by 1999 approximately 20,000 individuals associated or supporting the revolutionary Islamic organizations were put in detention.

To understand the lack of reaction on the part of the USA regarding the increasingly violent measures that the Egyptian president would resort to, one needs to understand the development of the American policy towards Egypt over the larger time span. The mutually advantageous cooperation required adjustments and the understanding of strategic objectives. The enduring American relationship with Mubarak' regime illustrates the point very well. At first, after Egypt signed the aforementioned peace treaty with Israel back in 1979, it was rewarded by the United States with significant foreign assistance, both military and financial. The superpower also pledged, albeit in an implicit manner, to support Egypt against any enemies and possible threats: both on domestic land and coming from abroad (Neack, 2013: 190).

Later, in the final years of the Cold War, Egypt's role was that of an important client state. At the dawn on the $21^{\text {st }}$ century, the continuing Mubarak's regime gained a wholly new importance to the USA, measured by Egypt's capability of suppressing sources of Islamic fundamentalism. It can be safely assumed that part of the American policy was based on identifying and preventing possible threats to Israel. Particularly, in the aftermath of the 9/11 terrorist attacks, Egypt's partnership proved vital to the USA and its foreign policy, even though various neoconservative factions suggested a more decisive 'forced' promotion of democracy throughout the entire Middle East. The American foreign diplomacy understood the necessity to maintain the convenient status quo, and instead opted to allow Mubarak his freedom to govern Egypt as he willed. His value as a substantial counterweight to militant Islamic organizations remained high and more important than ever before. This attitude was especially true for President George W. Bush's administration characterized by its deepest concerns about maintaining an approach against a vast variety of militarized threats (ibidem). 
While Egypt was the first country in the region to join the allied forces during the First Gulf War, Mubarak did not support the military involvement in Iraq in 2003, and generally disagreed with the progress of the campaign. He argued, instead, that solving the Israeli-Palestinian conflict was a matter of a higher priority. Furthermore, the Egyptian president expressed his fear that "a hundred Bin Ladens" would emerge in the aftermath of the conflict, as reported by the CNN (Mubarak warns, 2003). Towards the end of the American involvement, $\mathrm{H}$. Mubarak would oppose the American plan once again, believing that the immediate withdrawal of the US forces from Iraq would most probably lead to the eruption of chaos, rebellions and reins of anarchy (Egypt: U.S., 2006).

\section{FINAL DAYS OF MUBARAK'S REGIME}

Notably, according to the previously classified communique later released to the public via WikiLeaks, the US Ambassador Margaret Scobey stated in 2009 that speculative remarks aside, it remained practically unknown who would succeed Mubarak at the position of Egypt's leader in 2011 (Scobey, 2009). According to the same report, president's son Gamal Mubarak was at that time considered as the most probably successor. This line of speculation was mentioned in by Awolaja in Nigerian Tribune in the negative light - the journalist described a potential succession of presidency by Gamal Mubarak as nothing but 'hereditary pseudo-monarchy' (Awolaja, 2010). Foreign observers and governments could merely speculate and consider other possible candidates including chief of intelligence Omar Suleiman (nota bene, the next vice president of Egypt), or Secretary-General of the Arab League Amr Moussa. However, both President Mubarak and his son stated that the multi-candidate system that was already used during the previous election in 2005 introduced more transparency into the political process (Shahine, 2010).

The ruling National Democratic Party, also nicknamed Mubarak's party (Ray, 2013: 332), of Egypt initially upheld the information that Hosni Mubarak was to represent the party as the sole candidate during the elections of 2011. Due to the rising social unrest, Mubarak made a public statement that he was not intending to run for another term. The crowd remained unconvinced and unsatisfied with and the protests continued, even after a subsequent statement by Vice-President of Egypt stating that Mubarak's son would not stand in the presidential elections.

It must be underlined that during his multi-term presidency, Mubarak maintained the conditions of the Camp David Accords unaltered. The successfully concluded and long-standing treaty between Egypt and Israel signed in 1978 was brokered by the USA - from this perspective, the Egyptian president proved himself as an honest political partner. In the year to follow, Mubarak would host meetings concentrating on resolving the Israeli-Palestinian conflict. Considering the evidence provided so far, it must be admitted that in the dialogue between Egypt and the USA, Mubarak was a definite advocate of settling the situation in Israel as a matter of utmost priority to secure peace and stability in the Middle East. The president also personally served as a broker between the sides of the conflict (Sharp, 2009: 43). 
There are more facts indicating the instrumental role of $\mathrm{H}$. Mubarak in the improvement of the Israeli-Palestinian relations. According to Telushkin, H. Mubarak was planning to meet Menachem M. Schneerson, one of the most charismatic orthodox Jewish rabbi, despite the fact that the latter man was not convinced in the sincerity of Mubarak's intentions (Telushkin, 2014: 209).

Over a decade later, Hosni Mubarak hosted an emergency summit in 2000; the meeting was arranged in Sharm el-Sheikh, where the Israeli and Palestinian party could discuss and settle the issues that would otherwise lead to the escalation of the Israeli-Palestinian conflict, especially the rising crises in Israel, Gaza and the West Bank. America was brokering the diplomatic effort with President Clinton present at the summit along Palestinian Chairman Yasser Arafat, Prime Minister Ehud Barak from Israel, King Abdullah of Jordan. The meeting was also attended by NATO Secretary General Javier Solana, and United Nations Secretary General Kofi Annan (Bregman, 2002: 213).

With American security interests deeply involved in the Middle East, Egypt's support was crucial. Sufficient to state that President Clinton had, by that time, invested seven years of his two-terms making considerable efforts to restore peace between the conflicting parties. Should the skirmishes that began in 2000 erupt into an all-out war, the hitherto achievements would most probably be unraveled and void. The matter could be considered urgent in light of the fact that the summit took place only months before the end of Clinton's second term. Thus, containing the conflict at its onset as well as preserving the possibility to negotiate a future peace treaty were of importance to both Egypt, intending to strengthen its position in the region as a political broker, and the United States.

Despite the gradually developing unrest in Egypt, H. Mubarak continued to be involved in the activities of the Arab League, where he supported efforts of other Arab leaders to attain political stability and lasting peace in the entire region. For instance, during the Beirut Summit held on March 28, 2002, the league decided to adopt the Arab Peace Initiative - a plan to gradually bring the Arab-Israeli conflict to an end (The Arab Peace Initiative, 2002). Several years later, in June 2007, President Mubarak hosted another summit meeting at Sharm el-Sheik, while in 2008, Egypt brokered a pause in hostile activities between Israel and Hamas (Gutkin, 2008).

According to Ray, even during the final days of H. Mubarak's regime, his party stressed the important position of Egypt for the world, especially the USA - a cooperation formed and sustained thanks to H. Mubarak's continued efforts (Ray, 2013: 332). The politicians urged the crowd to cease protests and demonstrations allegedly instigated by the opposition, including Muslim Brotherhood, as the destabilization of the situation in Egypt could disrupt the flow of material aid offered by the USA for at least three decades propelling the economic development in the country. Interestingly, American diplomacy did not oppose Mubarak's 'extended' presidency as it provided a sense of continuity to the American-Egyptian cooperation. When asked whether the Egyptian president should relinquish his power Vice President Joe Biden stated as follows:

\footnotetext{
"Mubarak has been an ally of ours in a number of things. And he's been very responsible on, relative to geopolitical interest in the region, the Middle East peace efforts, the actions Egypt has taken relative to normalizing relationship with [...] Israel. [pause] I would not refer to him as a dictator" (Murphy, 2011).
} 
Note how the quoted excerpt clashes ideologically with Rice's statement presented earlier in this paper. In contrast, Biden's assertion voices a covert appeal of the skewed image of internal, domestic business-driven American Democracy. Clearly, the quoted fragment points to the pragmatism of the American policy towards Egypt. What was implied was that as a regime supporting the U.S. guidelines concerning its foreign policy aims was automatically deemed 'democratic'. Egypt had been a partner of unique strategic importance - it was geared towards maintaining peace with Israel, a state strongly supported by the USA. By losing the 'soft' diplomatic grip on the North African country, it would become considerably more difficult for the United States to provide Israel with sufficient support leading to potential domestic problems (Ray, 2013: 332).

Thus, H. Mubarak's eventual resignation saved America the problem of support in Egypt divided between practical implications and the concept of democracy whose presence had been diminishing in Egypt with each new year of Mubarak's reins.

$* * *$

The relations between Egypt and the USA during Hosni Mubarak's regime are marked by continuity and varying degrees of commitment. Despite considerable financial rewards delivered by the United States in return for Egypt's prompt assistance during the First Gulf War, the superpower could not count on similar enthusiasm during the second military campaign in Iraq-Egypt did not condemn American actions, but antagonized the resolutions made prior to and following the invasion.

In general, the American policy towards Egypt within the analyzed timeframe is based on a diplomatic trade - Egypt agreed to play the role of a peace-keeping state in the Middle East supporting activities that could facilitate maintaining peace between Israel and the Arab states. In return, the USA offered financial aid and help during negotiations aiming to reduce Egypt's debts abroad.

It is difficult to state precisely, to what extent Egypt was diplomatically 'vasalized' by the United States under the pretence of spreading democracy in the region. The problem of the USA consisting in adjusting its foreign policy to its domestic or "national' interest is not a new phenomenon. History had previously witnessed the hasty recognition of the state of Israel in 1948, the prolonged intensive efforts of almost every American president to become involved in the Israeli-Palestinian conflict, and opposition to military development in Iran - a chief and one of the most powerful enemy to Israel (Ray, 2013: 335).

As far as the portrait of H. Mubarak as a cooperating leader is concerned, the dark vision of his yielding to the will of the American government could be attributed to his lust for material profit, as evident through multiple accusations of corruption and embezzlement. From such a perspective, the Egyptian leader could be viewed as an opportunist ally. However, one can also point to the fact that by participating in innumerable key events, meetings, and summits in the region as well as hosting them, brokering agreements and treaties, and taking an active part at the American side, allowed Egypt to rise through the ranks of Middle Eastern and North African states.

To bring the subject to a close, Egypt has fit well into the American policy of unipolarity in international politics. In a model of distribution of power, where one 
powerful state exerts most of the total cultural, economic, as well as military influence, Egypt received 'special' treatment, so to speak, as did the country's controversial leader who managed to maintain his office as President for multiple terms. In Neack's words, unipolarity as a permanent characteristic of American foreign policy is not likely to change diametrically. Obama's administration no longer considers the idea of other powers rising as a threat to the USA - an approach that might, in theory, diminish the role of Egypt and the significance of the offered aid (Neack, 2013: 190).

In fact, it can be speculated that if George W. Bush's administration had been in charge during the time of Arab Awakening as it hit Tahrir Square in January 2011, President Mubarak could count on the previously guaranteed American support. The United States would likely opt to defend their strategic partner to counterweight the threat of militant Islam, also as part of the global War on Terror. However, Obama's administration found the possibility of Mubarak's regime being overthrown as an insufficient concern to mobilize a military support (ibidem).

\section{BIBLIOGRAPHY}

Awolaja A. (2010), Between Nigeria and Egypt's presidential crises, "Nigerian Tribune", March 24, http://www.webcitation.org/5vrcMHuEg (15.01.2015).

Bregman A. (2002), Israel's Wars: A History Since 1947, London-New York.

El Tohamy O. M. (1981), Egypt's Hosni Mubarak picks up Sadat's reins: profile, "The Christian Science Monitor", 14.10.1981, http://www.csmonitor.com/1981/1014/101447.html/\%28page\%29/2 (14.01.2015).

Egypt: U.S. withdrawal would hurt Iraq (2006), "USA Today", 9.04.2006, http://usatoday30.usatoday.com/news/world/iraq/2006-04-09-egypt-comments_x.htm (15.01.2015).

Foreign Relations of The United States, 1969-1976, Vol. XXVI, Arab-Israeli Dispute, 1974-1976, Document 195, http://history.state.gov/historicaldocuments/frus1969-76v26/d195 (14.01.2015).

Gutkin S. (2008), Hamas offering Israel truce, not peace, "USA Today", 12.03.2008, http://usatoday30.usatoday.com/news/world/2008-03-12-374518999_x.htm (15.01.2015).

Jordan B. J., Pauly R. J. (2007), The Centrality of Egypt to the Future, in: Strategic Interests in the Middle East: Opposition and Support for US Foreign Policy, (eds.) J. Covarrubias, T. Lansford, Hampshire.

Kalpakian J. (2007), The United States and the Arab League, in: Strategic Interests in the Middle East: Opposition and Support for US Foreign Policy, (eds.) J. Covarrubias, T. Lansford, Hampshire.

McDermott A. (2013), Egypt from Nasser to Mubarak (RLE Egypt): A Flawed Revolution, London-New York.

Mubarak: From popular President to hated dictator (2011), "The Siasat Daily", 9.02.2011, http://www.siasat.com/english/news/mubarak-popular-president-hated-dictator (14.01.2015).

Mubarak warns of '100 bin Ladens (2003), "CNN International”, 1.04.2003, http://edition.cnn.com/ 2003/WORLD/meast/03/31/iraq.egypt.mubarak.reut/ (15.01.2015).

Murphy D. (2011), Joe Biden says Egypt's Mubarak No Dictator, He Shouldn't Step Down, “The Christian Monitor", 27.01.2011, http:/www.csmonitor.com/World/Backchannels/2011/ 0127/ Joe-Biden-says-Egypt-s-Mubarak-no-dictator-he-shouldn-t-step-down (15.01.2015). 
Neack L. (2013), The New Foreign Policy: Complex Interactions, Competing Interests, Lanham.

Profile: Hosni Mubarak (2014), "BBC News Middle East”, 29.11.2014, http://www.bbc.com/news/ world-middle-east-12301713 (15.01.2014).

Ray J. L. (2013), American Foreign Policy and Political Ambition, Thousand Oaks.

Scobey M. (2009), Scenesetter: President Mubarak's visit to Washington, "WikiLeaks”, http://wikileaks.ch/cable/2009/05/09CAIRO874.html (15.01.2015).

Shahine A. (2010), Egypt's Ruling Party Tightens Grip as Mubarak Succession Nears, "Bloomberg”, 25.11.2010, http://www.bloomberg.com/news/2010-11-24/egypt-s-ruling-party-tightens-gripbe.ore-vote-as-mubarak-succession-nears.html (25.01.2015).

Sharp J. M. (2009), Egypt: Background and U.S. Relations, Washington, DC: Congressional Research Service.

Telushkin J. (2014), Rebbe: The Life and Teachings of Menachem M. Schneerson, the Most Influential Rabbi in Modern History, New York.

The Arab Peace Initiative (2002), http://www.al-bab.com/arab/docs/league/peace02.htm (15.01.2015).

The IMF's model pupil (1999), “The Economist", 18.03.1999, http://www.economist.com/node/ 319594/print?story_id=319594 (14.01.2015).

\begin{abstract}
American foreign policy towards Egypt during almost three decades of Mubarak's career as first vice-president, and later president of Egypt. The material underlines the impact of Mubarak's personality, career and political style on the overall shape of American cooperation with Egypt. Egypt is described as an inherent element of the American foreign policy-making processes. Its most notable role is that of a mediator and facilitator in the Arab-Israeli conflict - in fact, Mubarak at times ventured his country's position in the Middle East and North Africa (MENA) region to conduct and support peace talks, much to the US approval. In return, Egypt could count on considerable financial aid to maintain its already commendable military might, and develop civic structures.

Mubarak's power was always associated with his status as metaphorical 'eyes and ears' of Egyptian army - a position that brought the Egyptian president considerably appreciation on the American part. Mubarak is shown as a leader whose rein relied on cold calculation, pre-planning, unwillingness to improvise and act quickly, and 'controlled' risk taking.
\end{abstract}

Key words: U.S. foreign policy, Egypt, H. Mubarak, American-Egyptian bilateral relations

\title{
POLITYKA ZAGRANICZNA STANÓW ZJEDNOCZONYCH WOBEC EGIPTU ZA RZĄDÓW H. MUBARAKA
}

\section{STRESZCZENIE}

Niniejsze opracowanie omawia schematy dotyczące amerykańskiej polityki zagranicznej wobec Egiptu w trakcie rządów Hosni Mubaraka. Podkreślono wpływ osobowości i politycznego stylu lidera, jak również tła historycznego na kształtowanie się kooperacji między USA a Egiptem, z wyraźnym zaznaczeniem roli bliskowschodniego partnera jako stałego elementu amerykańskiej polityki zagranicznej w regionie. Egipt jest ukazany w roli mediatora i koordynatora w konfliktach na szczeblu regionalnym, odpowiedzialnego za organizację, prowadzenie 
i wspieranie mediacji pokojowych. W zamian za aktywną postawę proamerykańską, Egipt mógł liczyć na znaczną pomoc ekonomiczną, aby rozwijać istniejący, uznany potencjał militarny oraz rozbudowywać struktury cywilne.

Analiza wychodzi poza ramy obopólnie korzystnej współpracy, wpływów w regionie oraz osiaganych profitów. H. Mubarak jest przedstawiony jako krytyk niektórych posunięć związanych z amerykańską obecnością na Bliskim Wschodzie: począwszy od Porozumienia Camp David z roku 1978, aż do kampanii zbrojnej w Iraku w 2003 roku. Z drugiej strony, Egipt został ukazany także jako modelowy przykład współpracy z USA od momentu jego zaangażowania w wyzwolenie Kuwejtu. Pozycja polityczna H. Mubaraka związana była z jego wcześniej zyskaną reputacją jako "oczu i uszu” egipskiej armii - istotnego źródła aprobaty ze strony USA. Rządy egipskiego lidera opierały się na zimnej kalkulacji, wczesnym planowaniu, niechęci do improwizacji i podejmowania szybkich działań oraz podejmowaniu ograniczonego ryzyka.

Słowa kluczowe: polityka zagraniczna USA, Egipt, H. Mubarak, stosunki amerykańsko-egipskie 